\title{
Treatability of organic matter derived from surface and subsurface waters of drinking water catchments
}

\author{
John Awad ${ }^{a}$, John van Leeuwen ${ }^{\mathrm{a}, \mathrm{c}, \mathrm{d}, *}$, Joel Liffner ${ }^{\mathrm{a}}$, Christopher Chow ${ }^{\mathrm{a}, \mathrm{b}, \mathrm{c}}$, Mary Drikas ${ }^{\mathrm{a}, \mathrm{b}, \mathrm{c}}$ \\ ${ }^{a}$ Centre for Water Management and Reuse, School of Natural and Built Environments, University of South Australia, South Australia 5095, Australia \\ ${ }^{\mathrm{b}}$ Australian Water Quality Centre, SA Water Corporation, 250 Victoria Square, Adelaide, South Australia 5000, Australia \\ ' SKLEAC, Research Centre for Eco-environmental Sciences, Chinese Academy of Sciences, P.O. Box 2871, Beijing 100085, China \\ d Barbara Hardy Institute, University of South Australia, South Australia 5095, Australia
}

\section{H I G H L I G H T S}

- DOM not complexed with clay is less amenable to removal by alum.

- Lowest alum dose rates were for waters from native vegetation on sandy soil.

- Soil-water from prominent O horizon sites show similarity in DOM treatability.

\section{A R T I C L E I N F O}

\section{Article history:}

Received 9 June 2015

Received in revised form 15 September 2015

Accepted 16 September 2015

Available online 23 October 2015

Handling editor: Xiangru Zhang

\section{Keywords:}

Coagulation

DOM

F-EEM

Landuse

Soil texture

\begin{abstract}
A B S T R A C T
The treatability of NOM present in runoff and subsurface waters from discrete zero-order catchments (ZOCs) with three land management practices (Australian native vegetation, pine plantation, grasslands) on varying soil textures of a closed drinking water reservoir-catchment was investigated. Subsurface water samples were collected by lysimeters and shallow piezometers and surface waters by installation of barriers that diverted waters to collection devices. For small sample volumes collected, a 'micro' jar testing procedure was developed to assess the treatability of organics by enhanced coagulation using alum, under standardised conditions. DOM present in water samples was quantified by measurement of DOC and UV absorbance (at $254 \mathrm{~nm}$ ) and characterized using these and F-EEM. The mean alum dose rate (mg alum per mg DOC removed or Al/DOC) was found to be lower for DOM from sandy soil ZOCs (21.1 \pm 11.0 Al/DOC) than from clayey soil ZOCs (38.6 \pm 27.7 Al/DOC). ZOCs with Pinus radiata had prominent litter layers $(6.3 \pm 2.6 \mathrm{~cm})$, and despite differences in soil textures showed similarity in DOM character in subsurface waters, and in alum dose rates $(22.2 \pm 5.5 \mathrm{Al} / \mathrm{DOC})$. For sandy soil ZOCs, the lowest alum dose rates $(16.5 \pm 10.6 \mathrm{Al} / \mathrm{DOC})$ were for waters from native vegetation catchment while, for clayey soil ZOCs, waters from pine vegetation had the lowest alum dose rates $(23.0 \pm 5.0 \mathrm{Al} / \mathrm{DOC})$. Where $\mathrm{ZOCs}$ have a prominent $\mathrm{O}$ horizon, soil minerals had no apparent influence on the treatability of DOM.
\end{abstract}

(c) 2015 Elsevier Ltd. All rights reserved.
Abbreviation: \%DOC $\mathrm{Rem}_{\mathrm{R}} @ \mathrm{ED}$, percentage removal of DOC at enhanced alum dose; $\% \mathrm{DOC}_{\mathrm{Rem}} @ \mathrm{HD}$, percentage removal of DOC at high alum dose; $\mathrm{Al} / \mathrm{DOC}$, alum dose rate at enhanced dose; C, DOC removal rate co-efficient; DOC, dissolved organic carbon; $\mathrm{DOC}_{\mathrm{C}}$, coagulable $\mathrm{DOC}$; $\mathrm{DOC}_{\mathrm{NC}}$, non-coagulable DOC; $\mathrm{DOC}_{\mathrm{R}}$, DOC residual after treatment by alum; DOM, dissolved organic matter; ED, enhanced alum dose; FA, fulvic-like components; G, grass; HA, humic-like components; HD, high alum dose; HMW, high-molecular weight; MQW, High purity Milli-Q water; NV, native vegetation; P, pine; PI, protein1-like components; PII, protein2-like components; S, sandy soil; SC, sandy clay soil; SCL, sandy clay loam soil; SL, sandy loam soil; SMP, soluble microbial protein-like components; SpCol, Specific colour; SUVA, specific UV absorbance; $\mathrm{UV}_{254}$, UV absorbance at wavelength $254 \mathrm{~nm}$; ZOCs, zero-order catchments.

* Corresponding author. Centre for Water Management and Reuse, University of South Australia, H3-26 Mawson Lakes Campus, Adelaide, South Australia 5095, Australia.

E-mail address: John.vanleeuwen@unisa.edu.au (J. van Leeuwen).

\section{Introduction}

Natural organic matter (NOM) present in raw waters of reservoirs used for drinking water supply can pose significant aesthetic problems and health risks that need to be addressed through treatment processing prior to supply. Dissolved organic matter (DOM), often the major component of NOM can be derived from two distinct sources: (1) allochthonous inputs derived from catchment sources and (2) autochthonous organic matter production from within the water body (e.g., reservoir), for example, by microbial activity (Sachse et al., 2005) and by photosynthesis. Water quality in catchment fed reservoirs is largely influenced by land management practices within the catchment (Bryan et al., 2009), and catchment properties such as vegetation type and loading (Naidu et al., 1993; Chantigny, 2003; Yang et al., 2013), topography 
(Ågren et al., 2007), climate (Chow et al., 2011; Yang et al., 2013) and soils (Nelson et al., 1992).

Dissolved organic matter (DOM) can have significant impacts on drinking water quality with potential concerns to public health. Such concerns include: (1) disinfection by-product formation when organics react with chemical disinfectants (Richardson and Postigo, 2012), (2) increase microbial regrowth in the drinking water distribution system (Drikas et al., 2003), and (3) increases colour, taste and odor levels in drinking water that can make it unacceptable by the community. The removal of organics that are the precursors of DBPs of health concern, is therefore of high importance. Coagulation and flocculation are the most widely used processes for removal of DOM from drinking water (Matilainen et al., 2010) even though it can only be partially removed. The treatability (or removal capacity) of organics present in drinking water by coagulation/flocculation is affected by the raw water alkalinity and the character of DOM (Chow et al., 2009). DOM is a complex assemblage of chemical structures (McElmurry et al., 2014) that varies in molecular weight and functionality (Matilainen et al., 2010). These include humic substances that are collections of diverse, relatively low molecular mass components forming associations stabilized by hydrophobic interactions and hydrogen bonds (Sutton and Sposito, 2005). The coagulation process has been reported to be more effective in the removal of high-molecular weight hydrophobic compounds than low-molecular weight hydrophilic compounds (Matilainen et al., 2010; Sillanpää and Matilainen, 2015).

Catchment surface runoff and stream waters generally have higher concentrations of organics that are more aromatic and humic in nature (Inamdar et al., 2012) than shallow and deep groundwater. This is attributed to either absorption of high molecular weight (Banaitis et al., 2006), hydrophobic and aromatic compounds (Ussiri and Johnson, 2004) to mineral soils or by microbial modification (Sun et al., 2013), as the DOM in waters move through the soil profile. Nelson et al. (1992) found that differences in concentrations of dissolved organic carbon (DOC) between streams are dependent on the adsorption capacities of the catchment soils. DOM present in catchment waters is influenced by vegetation loading and, in a comparative study, highest DOM concentrations were found from catchments under forest cover followed by grassland and then arable soils (Chantigny, 2003). Naidu et al. (1993) reported that DOC concentrations in water flow along the soil A horizon/B horizon boundary under pine plantation, was at least twice that under native woodland or pasture. The highest concentration of DOC released into subsurface waters can occur during the first seasonal rainfall event, demonstrating the importance of fresh litter material in generating high amounts of soluble organic matter (Chow et al., 2011).

Although several studies have reported an association between land management practices and NOM present in waters, as exemplified above, to date there have been few studies reported on the relationships between the qualities of waters within discrete landuse catchments and the treatment needs of waters for potable supply. Previously we reported the findings of a study (Awad et al., 2015) on the characters and concentrations of DOMs (measured as DOC) present in surface runoff and in the upper horizons of the soil profile in ZOCs, with distinct vegetation and soil texture. The results of that study showed that DOC concentrations of surface flow waters were similar or higher than of sub-surfaces waters. It was also found that waters from grass catchments had the least loading of DOM for a particular soil texture, as compared with native vegetation and Pinus radiata. The aim of the study reported here was to determine the treatability of DOMs present in surface and subsurface waters sourced from contrasting ZOCs of a drinking water reservoir catchment. In this study, DOC, UV absorbance at $254 \mathrm{~nm}$ and F-EEM data were acquired to characterize DOM before and after a 'micro' jar testing procedure, developed to assess the treatability of organics present in small volumes $(\sim 100 \mathrm{~mL})$ of subsurface water samples collected.

\section{Material and methods}

\subsection{Site descriptions and instruments}

This study was conducted in the Myponga reservoir-catchment $\left(35^{\circ} 22^{\prime}\right.$ to $35^{\circ} 25^{\prime} \mathrm{S}$ and $138^{\circ} 24^{\prime}$ to $138^{\circ} 28^{\prime} \mathrm{E}$ ) which is part of the Mount Lofty Ranges watershed, $50 \mathrm{~km}$ south of Adelaide, South Australia, Australia. The catchment area $\left(123 \mathrm{~km}^{2}\right)$ (Bryan et al., 2009) of the Myponga Reservoir (26,800 ML holding capacity) has high levels of organic loading ( $\left.15.0 \mathrm{mg} \mathrm{L}^{-1} \mathrm{DOC}\right)$ in Reservoir water. Six zero-order catchments (ZOCs), with distinct soil texture (sandy and/or clayey) covered by native vegetation, pine or grass, were selected for this study. ZOCs are largely non-channelized drainages common on hill-slopes and referred to as hollows or swales (Dietrich et al., 1987).

Land-uses, predominant vegetation, average slopes and detailed soil descriptions of ZOCs studied have been previously reported (Awad et al., 2015). The key features of the study sites are as follows: Site 1: native vegetation on sandy soil (NV-S); Site 2: pine on sandy soil (P-S); Site 3: grass on sand over sandy clay (G$\mathrm{S} / \mathrm{SC}$ ); Site 4: native vegetation on sandy clay loam over sandy clay (NV-SCL/SC); Site 5: pine on sandy clay loam over sandy loam (P-SCL/SL); Site 6: grass on sandy clay loam over sandy clay (G$\mathrm{SCL} / \mathrm{SC})$.

ZOCs were instrumented with surface runoff collection devices as detailed by Awad et al. (2015). Ceramic cup lysimeters were installed at depths of approximately 30 and $60 \mathrm{~cm}$ to capture soil water samples through application of a vacuum at $\sim 60$ psi. Subsurface through-flow water samples were collected by installation of $90 \mathrm{~mm}$ diameter PVC piezometers. The tops of piezometers were loosely capped.

The rainfall pattern of Myponga, South Australia, is strongly seasonal with hot dry summers and cool wet winters (in 2013, $643 \mathrm{~mm}$ rainfall occurred between June and November compared with $178 \mathrm{~mm}$ between December and May). Water samples were collected in winter and spring seasons (between June and November 2013). In summer-autumn seasons, neither surface water runoff nor subsurface water flow were recorded in any ZOCs.

\subsection{Water analyses}

\subsubsection{DOC concentrations and UV-Vis absorbance measurements}

The DOC and UV absorbance measurements were made of water samples, pre-filtered through $0.45 \mu \mathrm{m}$ pre-rinsed sterile cellulose membrane filters. DOC concentration was determined using a TOC analyser (Model 900, Sievers Instruments). UV-Visible light absorbances were measured using a spectro-photometer (UV120, MIOSTECH Instruments) for wavelengths from $200 \mathrm{~nm}$ to $700 \mathrm{~nm}$, using a quartz cuvette of $1 \mathrm{~cm}$ path length. Colour in Hazen Units (HU) was determined by absorbance at $456 \mathrm{~nm}$ using a $5 \mathrm{~cm}$ path length, glass cuvette and a platinum/cobalt standard (50 HU). Specific UV absorbance or SUVA (the ratio of absorbance at $254 \mathrm{~nm} \mathrm{~m} \mathrm{~m}^{-1}$ to the concentration of DOC), (Edzwald and Tobiason, 1999) and Specific colour (SpCol, the ratio of colour in HU to DOC concentration) were determined.

\subsubsection{Fluorescence excitation-emission matrix}

Fluorescence excitation-emission matrix (F-EEM) spectra were acquired (Model LS 55, PerkinElmer) to characterize NOM based on the relative abundances of humic (HA), fulvic (FA), protein1 
(PI), protein2 (PII) and soluble microbial protein (SMP)-like components. A series of emission spectra (over 280-600 nm) were acquired at $0.5 \mathrm{~nm}$ increments over excitation wavelengths between $200 \mathrm{~nm}$ and $500 \mathrm{~nm}$ at $5 \mathrm{~nm}$ increments. A high purity Milli-Q water (MQW) spectrum was subtracted from the spectra of samples. The method of Chen et al. (2003) was used in this study to identify five different EEM regions for each sample and to calculate the relative abundance of each organic group. Samples for F-EEM analysis were pre-diluted by addition of MQW to minimize the inner filter effect, and pre-filtered through $0.45 \mu \mathrm{m}$ pre-rinsed sterile cellulose membrane filters.

\subsubsection{Jar test and micro-jar test}

For testing of the treatability of the organics by alum, DOC concentrations of water samples, as collected, were standardized to $8.0 \pm 1.0 \mathrm{mg} \mathrm{L}^{-1}$ by addition of MQW. Standardized jar tests were performed at ambient temperature and at $\mathrm{pH} 6 \pm 0.1$ (Chow et al., 2009) using aluminium sulphate (alum), as $\mathrm{Al}_{2}\left(\mathrm{SO}_{4}\right)_{3} \cdot 18 \mathrm{H}_{2} \mathrm{O}$. The $\mathrm{mEnCo}^{\odot}$ model (van Leeuwen et al., 2009) was used to determine six alum doses at $50 \%, 75 \%, 100 \%, 150 \%, 200 \%$ and $300 \%$ of the estimated dose, and then applied in jar tests. The $\mathrm{mEnCo}^{\circ}$ model was developed for prediction of alum doses that are required to maximize removal of DOC from raw waters, such as of rivers and reservoirs, used for potable water supply.

Because small volumes (several hundred millilitres) of subsurface water samples could only be collected using the lysimeters and the required volume for conventional jar testing is about 12 L per Gator jar, a micro jar test procedure was developed and applied. For this study, a shaker (Orbital shaker, Thermoline Scientific) was used for rapid and slow mixing. A square baffled jar (400 mL holding capacity) was used to ensure required mixing. Fig. 1a details the structure and dimensions of the baffled microGator jar. For micro-jar testing, alum and $\mathrm{pH}$ correction reagents were added to water samples $(100 \mathrm{~mL})$ and mixed as follows: for rapid mixing $150 \mathrm{rpm}$ for $1.0 \mathrm{~min}$ followed by $90-100 \mathrm{rpm}$ for $14 \mathrm{~min}$. Flocs were allowed to settle for $15 \mathrm{~min}$. The settled water samples were then filtered through Whatman No.1 and the filtered turbidity measured. Absorbance at UV254 nm was measured to compare results between conventional and micro jar test using surface water collected from Myponga Reservoir (Fig. 1b). The mean percentage difference in UV absorbance at $254 \mathrm{~nm}$ between conventional and micro jar test was calculated and found to be less than $1 \%$ (mean \pm standard deviation $=0.76 \pm 5.25 \%$ ).

\subsubsection{Enhanced coagulation dose}

In this study, enhanced (ED) alum doses (for maximizing DOC removal at an operationally acceptable coagulant dose) were calculated based on DOC removal, where an additional $10 \mathrm{mg} \mathrm{L}^{-1}$ of alum resulted in less than $0.15 \mathrm{mg} \mathrm{L}^{-1}$ DOC reduction (van Leeuwen et al., 2009). TableCurve ${ }^{\mathrm{TM}}$ software was used to develop a model of the relation between DOC residuals and alum doses i.e. an exponential decay function, (Equation (1)). The residual DOC at a high dose (HD, > 2 times the ED) was defined as the noncoagulable DOC, and that removed at HD defined as the coagulable DOC, in Equation (1) below.

$D O C_{R}=D O C_{N C}+D O C_{C} * e^{-(C * x)}$

where $\mathrm{DOC}_{\mathrm{R}}$ is the DOC residual ( $\mathrm{mg} \mathrm{L}^{-1}$ ) at a selected alum dose $\left(\mathrm{x}, \mathrm{mg} \mathrm{L}^{-1}\right), \mathrm{DOC}_{\mathrm{NC}}$ is the $\mathrm{DOC}$ residual at HD alum dose (noncoagulable $\mathrm{DOC}), \mathrm{DOC}_{\mathrm{C}}$ is the coagulable $\mathrm{DOC}\left(\mathrm{DOC}_{\text {initial }}-\mathrm{DOC}_{\mathrm{HD}}\right)$ and $\mathrm{C}$ is the $\mathrm{DOC}$ removal rate co-efficient determined from data of all jars of the jar test.

\section{Results and discussion}

\subsection{Characterization of DOM present in raw waters by UV absorbance and F-EEM}

At the pine sites, subsurface water samples were collected predominantly using lysimeters (with only one sample being able to be collected from a piezometer from the P-SCL/SL catchment). Surface water runoff at the pine site sub-catchments did not occur in the period of this study. Runoff and subsurface water samples were collected from the other ZOCs.

SUVA values correlate with the average molecular weights of aromatic compounds, and organics with high SUVA and high SpCol indicate the presence of high-molecular weight (HMW), hydrophobic compounds (Ødegaard et al., 2010). Average SUVA and SpCol, and average percentage abundances of organic components [humic- (HA), fulvic- (FA), and protein-like compounds (PI, PII and SMP)] in surface and subsurface water samples from the ZOCs are shown in Fig. 2.

SUVA and SpCol of DOMs in ZOC runoff and river waters were higher than reservoir water (Fig. $2 \mathrm{a}$ and $\mathrm{b}$ ). DOMs present in runoff and river waters had slightly higher average abundances of FA$(49 \pm 4 \%)$ and HA- $(31 \pm 2 \%)$ like compounds compared with reservoir water' ( $46 \pm 2 \%$ for FA-like and $29 \pm 2 \%$ for HA-like compounds) as shown in Fig. 2c. For clayey soil ZOCs with native vegetation or grass, runoff waters had higher levels of SUVA, SpCol and abundance of HA-like compounds compared with the corresponding subsurface waters. However, for the sandy soil ZOCs with native vegetation or grass, the runoff waters were similar to the corresponding subsurface flow.

For sandy soil ZOCs with native vegetation or grass, runoff and subsurface water samples contained DOM with higher levels of SUVA $\left(4.8 \pm 0.4 \mathrm{~L}\left(\mathrm{mg} \mathrm{m}^{-1}\right)\right.$, SpCol $\left(10.2 \pm 1.5 \mathrm{HU} \mathrm{L} \mathrm{mg}^{-1}\right)$ and
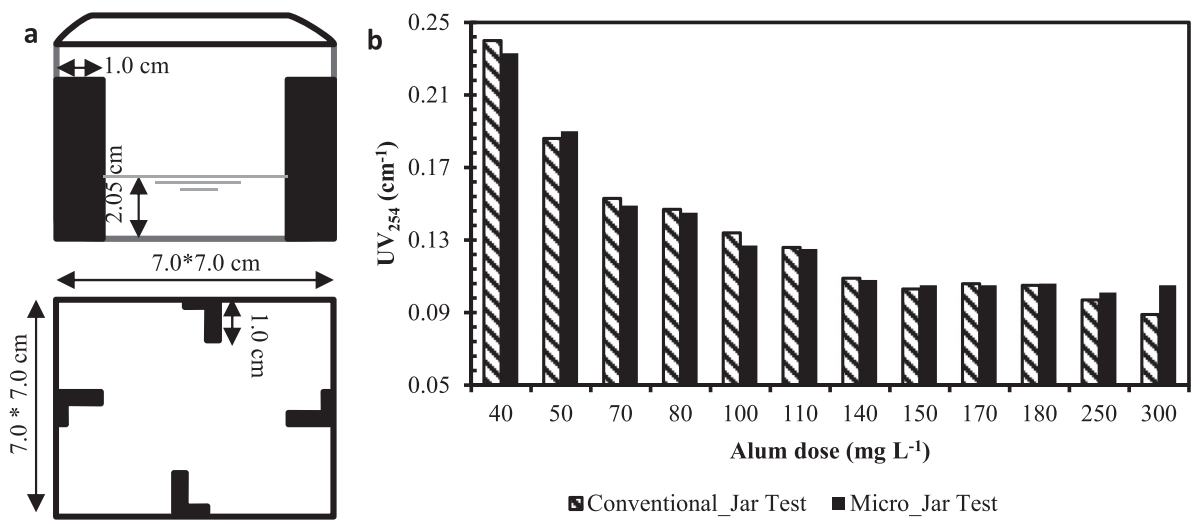

Fig. 1. a) Micro-Gator jar dimensions and b) UV absorbance at $254 \mathrm{~nm}$ for Myponga reservoir water after treatment with alum. 
higher abundances of FA- (48 $\pm 4 \%$ ), HA- (31 $\pm 4 \%$ ) like compounds than samples collected from the corresponding clay soil sites, (SUVA: $3.1 \pm 1.1 \mathrm{~L}(\mathrm{mg} \mathrm{m})^{-1}$; SpCol: $5.3 \pm 3.5 \mathrm{HU} \mathrm{L} \mathrm{mg}^{-1}$; FA-like: $45 \pm 5 \%$; HA-like: $23 \pm 7 \%$ ). In contrast, no such distinction was apparent for the pine sites for these parameters (Fig. 2) even though the clay levels were quite different (P-S: mean clay $5.5 \pm 2.3 \%$ vs. P-SCL/SL: mean clay $19.7 \pm 2.5 \%$ ).

For sandy soil ZOCs, the highest levels of SUVA, SpCol and the highest relative abundances FA-like compounds in subsurface soil waters were from the native vegetation site, followed by the grass and the $P$. radiata sites. For clayey soil ZOCs, the highest levels of these parameters were from $P$. radiata followed by grass and native vegetation sites. In general, the highest relative abundances of HAlike compounds and the lowest relative abundances of protein-like compounds (PI, PII and SMP) were from the $P$. radiata ZOCs.

Subsurface water samples collected by piezometers contained DOM with higher SUVA $\left(3.9 \pm 1.1 \mathrm{~L}(\mathrm{mg} \mathrm{m})^{-1}\right)$, SpCol $\left(7.8 \pm 3.1 \mathrm{HU} \mathrm{L} \mathrm{mg}{ }^{-1}\right)$ and higher abundances of FA-like $(50 \pm 3.0 \%)$ and HA-like $(29 \pm 8 \%)$ compounds than samples collected by lysimeters (SUVA: $2.9 \pm 1.2 \mathrm{~L}(\mathrm{mg} \mathrm{m})^{-1}$; SpCol: $4.9 \pm 8$ HU L mg ${ }^{-1}$; FA-like: $41 \pm 4 \%$; HA-like: $25 \pm 6 \%$ ). This indicates a general difference in the characteristics of DOM in waters collected by these two devices.

In previous studies (Leinweber et al., 2001; Chantigny, 2003) it has been reported that DOMs from soils under forests are of higher molecular weights than from arable/agricultural soils, and arable/agriculture soils contain relatively more lower molecular weight organic constituents, such as fulvic and hydrophilic acids. Kalbitz et al. (2003) reported that DOM from sub-surface waters under native vegetation has more humified compounds than from agricultural sites. Wilson and Xenopoulos (2009) reported that a greater proportion of croplands present in thirty-four watersheds
(Ontario, Canada) led to more DOM sourced from microbial activity. McElmurry et al. (2014) reported DOM of higher aromaticity present in runoff from forested compared with urban areas while, Sun et al. (2013) reported similar aromaticity of DOM sourced from forest, grassland and arable land based on UV absorbance data for two study locations in China (with Haplic, Kastanozem soil) and Canada (Albic Luvisol). In our study, the highest concentration of aromatic compounds (based on UV@254 nm absorbance) and the highest relative abundances of HMW and humic compounds present in waters of sandy soil ZOCs were of the Australian native vegetation ZOC. For the clayey soil sites, the highest levels were from the $P$. radiata ZOC. These findings indicate that soil properties and organic loading are key factors that determine DOM levels and their character in catchment waters.

\subsection{Alum dose and DOC removal}

Percentage reductions of DOC after standardized treatment using alum at $\mathrm{ED}\left(\% \mathrm{DOC} \mathrm{Rem}_{\mathrm{Re}} @ \mathrm{ED}\right)$ and the alum dose rates (mg alum per mg DOC removed) at $\mathrm{ED}(\mathrm{Al} / \mathrm{DOC})$ are presented in Fig. 3. The percentage reductions of DOC at $\mathrm{HD}\left(\% \mathrm{DOC}_{\mathrm{Rem}} @ \mathrm{HD}\right)$ are presented in Supplementary information (Fig. S1).

Percentage removals of DOC from catchment runoff and river waters were higher than reservoir water (Fig. 3a and S1). The $\mathrm{Al} / \mathrm{DOC}$ data showed a similar trend with values considerably lower in runoff and river water samples compared with reservoirs waters (Fig. 3b). Organics present in reservoirs comprise allochthonous and autochthonous NOM, and the latter is likely to be more recalcitrant to removal by coagulation (Fabris et al., 2008). Organics present in runoff waters had higher relative abundance of coagulable compounds (aromatic and humic compounds, Fig. 2) compared to reservoir waters.
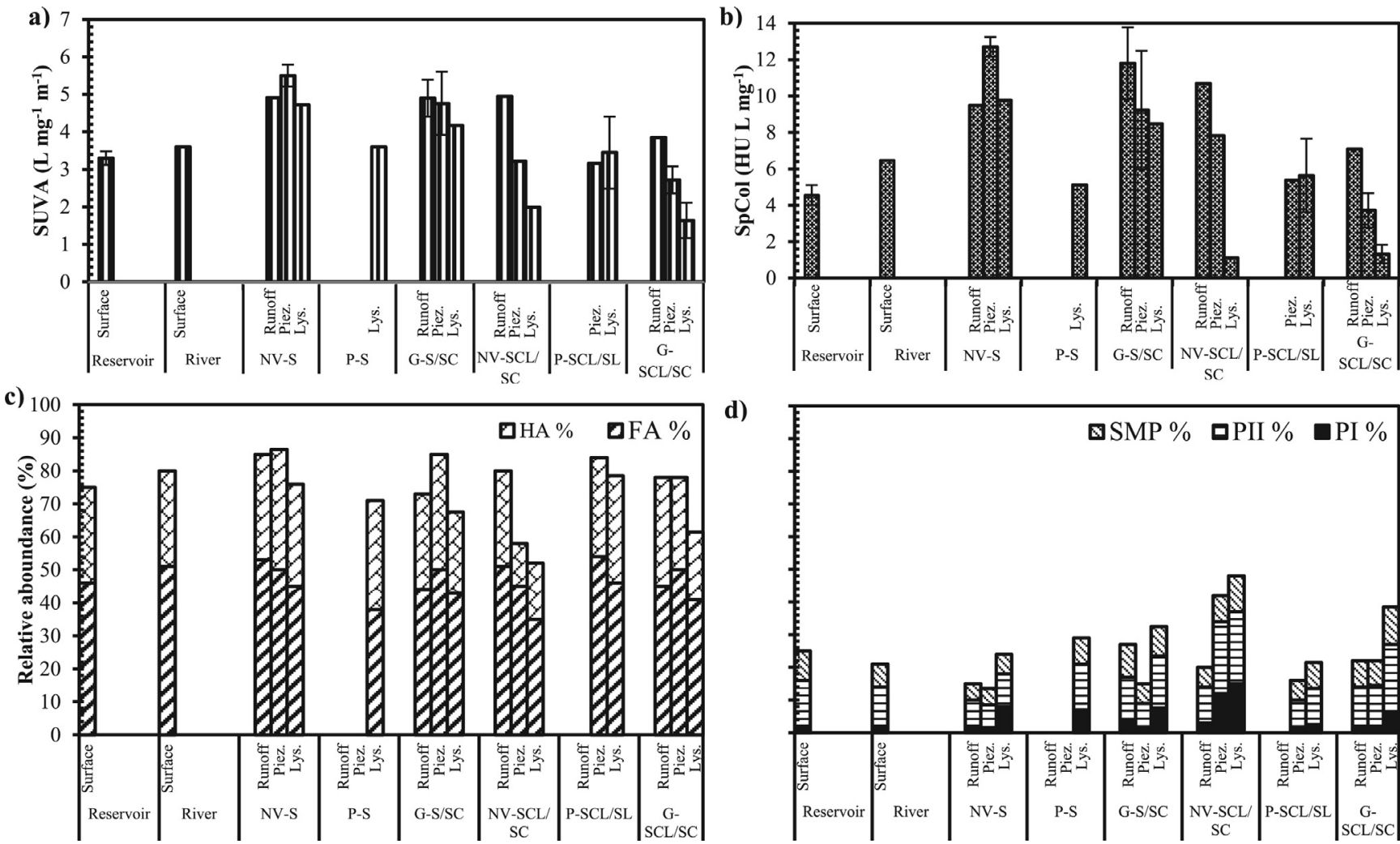

d)

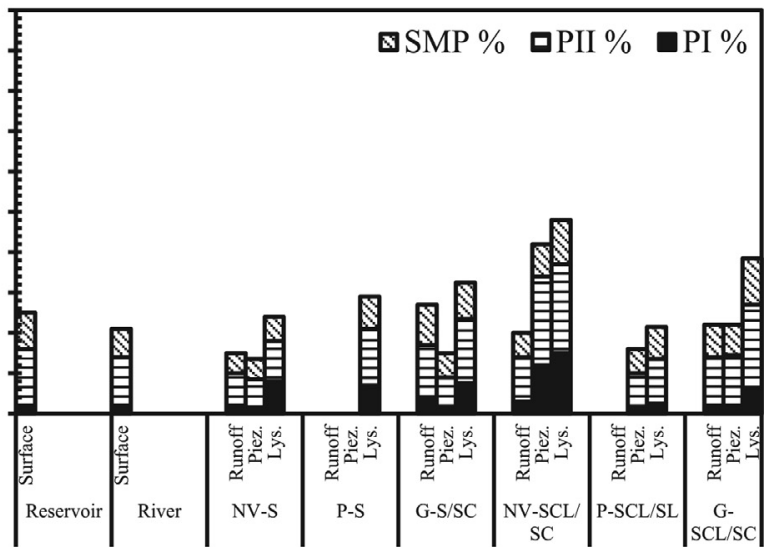

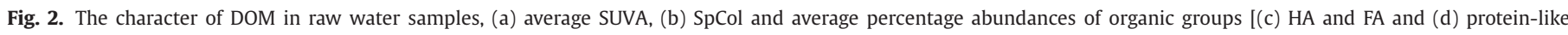
compounds] identified by F-EEM. Subsurface water values are the averages of two collection depths $(\sim 30$ and $\sim 60 \mathrm{~cm})$. 
a)

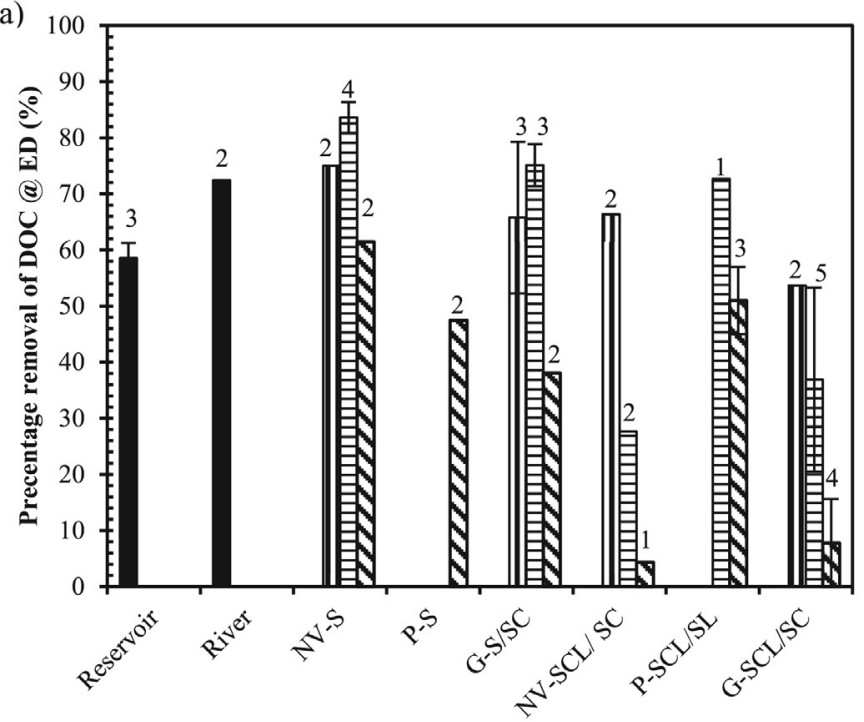

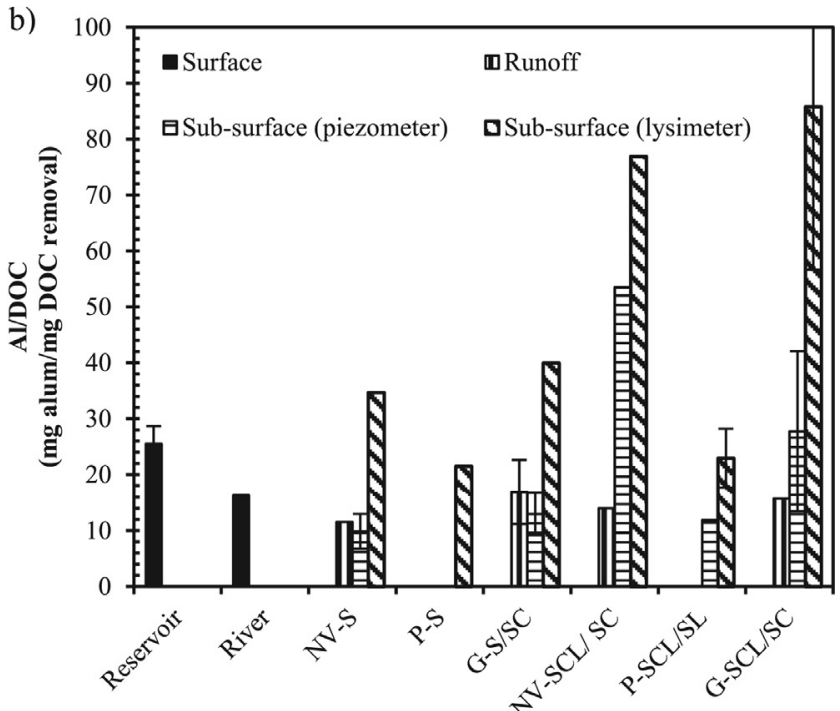

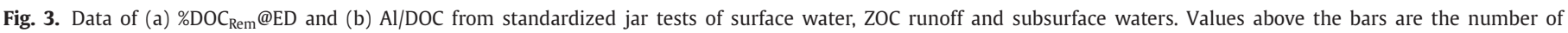
standard micro jar tests performed for each site.

For \%DOC $\mathrm{Rem}_{\mathrm{R}} @ \mathrm{ED}$ data, larger differences were found between runoff and subsurface waters collected by lysimeters (NV-S $\Delta 54 \%$; G-S/SC $\Delta 81 \% ;$ NV-SCL/SC $\Delta 184 \% ;$ G-SCL/SC $\Delta 70 \%$ ) than from piezometers (NV-S $\Delta 34 \%$; G-S/SC $\Delta 27 \%$; NV-SCL/SC $\Delta 57 \%$; GSCL/SC $\Delta 9 \%$ ). This indicates that the character of DOM (Fig. 2) present in runoff waters has greater resemblance to subsurface waters collected by piezometers than lysimeters. The Al/DOC values of subsurface waters from piezometers were significantly lower than the corresponding waters from lysimeters (Fig. 3b). Marques et al. (1996) reported major differences in the qualities of waters collected by zero tension plate and ceramic cup tension lysimeters. They suggested that solutes in waters collected by the zero tension plate lysimeter are affected mainly by organic matter mineralization in the forest floor and the A1 horizon, and these undergo little interaction in vertical transfer in the soil. In contrast, solutes in waters of the tension lysimeter are likely to be more in equilibrium with respect to key biogeochemical processes (e.g., mineralization, ion-exchange).

For the sandy soil ZOCs with native vegetation or grassland, the \%DOC removals by alum treatment were greater in subsurface water samples (collected by piezometers) than runoff waters, indicating that organic compounds in the runoff waters were less amenable to removal by coagulation than the subsurface waters. In contrast, runoff water samples collected from clay soil sites had higher \%DOC removals than subsurface waters (Fig. 3a and S1). The $\mathrm{Al} / \mathrm{DOC}$ data showed the same trend with values lower in subsurface waters than surface flow waters from sandy sites and conversely, higher in subsurface waters compared with surface flow waters from clayey sites (Fig. 3b).

For native vegetated ZOCs, the average \% $\mathrm{DOC}_{\mathrm{Rem}} @ \mathrm{ED}$ was higher in waters of the sandy soil (clay $5 \pm 3 \%)$ catchment $(\sim 74 \pm 9 \%)$ and lower in waters of the clayey (clay $24 \pm 10 \%)$ site ( $33 \pm 26 \%$ ) than reservoir water ( $\sim 59 \pm 2 \%)$. Organics from the NV-S had high relative abundances of humic and aromatic compounds compared with organics from NV-SCL/SC (Fig. 2). Grassland ZOCs showed the same trend with \%DOC $\mathrm{Rem}_{\mathrm{E}} @ \mathrm{ED}$ considerably lower for the clayey soil (clay $22 \pm 7 \%)$ catchment $(\sim 33 \pm 19 \%)$ than the sandy soil (clay $15 \pm 16 \%)$ catchment $(\sim 60 \pm 16 \%)$. The Al/DOC showed the same trend with values higher in water samples collected from clayey sites compared with sandy sites. The average Al/DOC val- ues were $16.5 \pm 10.6$ for NV-S and $48.1 \pm 26.6$ for NV-SCL/SC and $24.6 \pm 13.3$ for $\mathrm{G}-\mathrm{S} / \mathrm{SC}$ and $48.6 \pm 41.5$ for $\mathrm{G}-\mathrm{SCL} / \mathrm{SC}$.

Comparison of the two $P$. radiata sites was limited due to few water samples being able to be collected (only by lysimeters). Despite the P-SCL/SL site having a higher percentage of clay $(19.7 \pm 2.5 \%)$ than P-S $(5.5 \pm 2.3 \%)$, the Al/DOC for the P-SCL/SL site $(23.0 \pm 5.0)$ was similar to the P-S $(21.5, \mathrm{n}=2)$, see Fig. $2 \mathrm{~b}$. The percentage removals of DOC from the P-SCL/SL site ( $51 \pm 6 \%$ at ED and $55 \pm 8 \%$ at HD) were similar to those of the P-S site ( $47 \%$ at ED and 57\% at HD), see Fig. 3a and S1.

\subsection{Characterization of DOM in alum treated waters, by UV absorbance and F-EEM}

Average SUVA and SpCol data and the relative abundances of organic compound groups identified by F-EEM in ED and HD alum treated waters are shown in Fig. 4 and in Supplementary information (Table S1), respectively.

Alum treated waters had lower SUVA and SpCol values than raw waters, as expected. The relative abundances of protein-like compounds (PI-like, PII-like and SMP-like) in the alum treated waters were higher than in raw waters, sourced from the catchments (Figs. $2 \mathrm{~d}$ and $4 \mathrm{~d}$ and Table S1). This is attributed to the greater effectiveness of coagulation in removing HA-like and FA-like compounds compared with protein-like compounds, as reported by Sanchez et al. (2013) and in removal of aromatic and hydrophobic compounds, as reported by Ødegaard et al. (2010).

Residual DOM in alum treated water samples sourced from catchment runoff and river waters had lower relative abundances of HA- and FA-like compounds than in reservoir water (Fig. 4c and Table S1). In contrast, treated waters sourced from catchment runoff and river waters had higher SUVA and SpCol levels compared with treated reservoir water.

Residual DOM in treated waters collected from sandy soil ZOCs had lower relative abundances of HA-like (mean $12 \pm 3 \%$ at ED and $10 \pm 2 \%$ at HD) and slightly lower abundances of FA-like (mean $38 \pm 7 \%$ at ED and $33 \pm 5 \%$ at HD) compounds than in the corresponding clayey soil ZOCs $(18 \pm 3 \%, 16 \pm 4 \%, 41 \pm 5 \%$ and $37 \pm 5 \%$, respectively). These data indicate that HA- and FAlike organic compounds in water samples from sandy soil ZOCs 

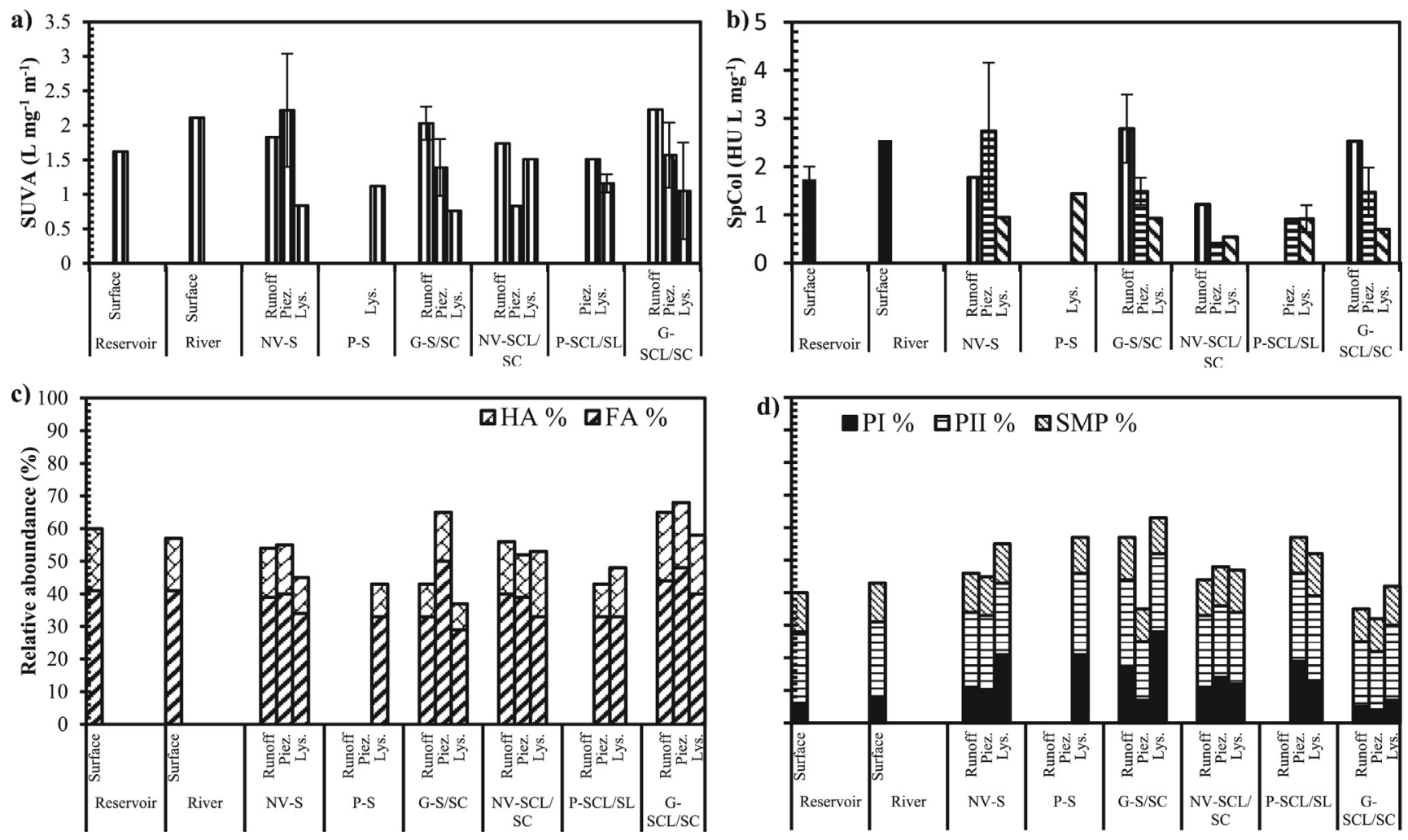

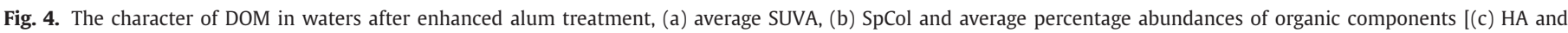
FA like and (d) Protein-like] identified by F-EEM.

were generally more amenable to removal by coagulation than of clay soils. The SUVA levels in treated waters from sandy soil ZOCs $\left[1.5 \pm 0.6 \mathrm{~L}(\mathrm{mg} \mathrm{m})^{-1}\right.$ at ED and $1.4 \pm 0.4 \mathrm{~L}\left(\mathrm{mg} \mathrm{m}^{-1}\right.$ at HD] were similar to those of clay sites $\left[1.5 \pm 0.5 \mathrm{~L}(\mathrm{mg} \mathrm{m})^{-1}\right.$ at ED and $1.5 \pm 0.5 \mathrm{~L}\left(\mathrm{mg} \mathrm{m}^{-1}\right.$ at $\left.\mathrm{HD}\right]$.

The highest relative abundances of protein-like compounds were found in treated waters sourced from $P$. radiata ZOCs (mean, $55 \pm 3 \%$ at ED and $57 \pm 2 \%$ at HD) followed by native vegetation ZOCs (mean, $48 \pm 4 \%$ at ED and $53 \pm 5 \%$ at HD) and then grass ZOCs (mean, $44 \pm 12 \%$ at ED and $48 \pm 8 \%$ at HD). Consistent with that, the lowest relative abundances of HA-like (mean, $13 \pm 3 \%$ at ED and $11 \pm 2 \%$ at HD) and FA-like compounds (mean, $33 \pm 1 \%$ at $\mathrm{ED}$ and $32 \pm 0 \%$ at $\mathrm{HD}$ ) were found from the $P$. radiata $\mathrm{ZOCs}$. The lowest SUVA (mean, $1.3 \pm 0.2 \mathrm{~L}(\mathrm{mg} \mathrm{m})^{-1}$ at ED and $1.1 \pm 0.2 \mathrm{~L}$ $(\mathrm{mg} \mathrm{m})^{-1}$ at HD) and SpCol (mean, $1.1 \pm 0.3 \mathrm{HU} \mathrm{L} \mathrm{mg}^{-1}$ at ED and $0.9 \pm 0.1 \mathrm{HU} \mathrm{L} \mathrm{mg}{ }^{-1}$ at HD) values were also found in treated waters from $P$. radiata ZOCs. These data indicate that HA-like, FA-like, aromatic compounds in water samples from $P$. radiata $Z$ OCs were the most amenable to removal by coagulation.

Treated subsurface water samples sourced from piezometers had residual organics with higher abundances of FA-like (44 $\pm 5 \%$ at ED and $37 \pm 6 \%$ at HD) and HA-like ( $16 \pm 3 \%$ at ED and $13 \pm 4 \%$ at HD) compounds than samples from lysimeters (34 $\pm 3 \%$, $31 \pm 3 \%, 14 \pm 4 \%$ and $12 \pm 5 \%$, respectively). The SUVA and SpCol values showed the same trend with values higher in piezometer waters compared with corresponding lysimeter waters, (Fig. 4 and Table S1).

\subsection{Characterization of DOM and enhanced alum dose prediction}

In model development for optimum alum dose determination based on the character of DOM, Equation (1) was initially used to calculate DOC residuals at alum doses (for alum doses to $300 \mathrm{mg} \mathrm{L}^{-1}$ at $5 \mathrm{mg} \mathrm{L}^{-1}$ increments). The optimum alum dose was calculated based on DOC removal where an addition of $10 \mathrm{mg} \mathrm{L}^{-1}$ of alum resulted in less than $0.15 \mathrm{mg} \mathrm{L}^{-1} \mathrm{DOC}$ reduction. The exponential decay function parameters $\left(\mathrm{DOC}_{\mathrm{NC}}, \mathrm{DOC}_{\mathrm{C}}\right.$ and C; Eq. (1)) were estimated as detailed below.

The sigmoid function (Eq. (2)) was fitted to describe the relationship between the ratio of DOC removal at $\mathrm{HD}$ dose [ $\left(\mathrm{DOC}_{\text {initial }}\right.$ - $\left.\left.\mathrm{DOC}_{\mathrm{HD}}\right) / \mathrm{DOC}_{\text {initial }}\right]$ and the character of DOM in the untreated waters [SUVA + Ln $(100 *$ SpCol $)]$. For this, data from jar tests $(\mathrm{n}=30)$ of samples collected from different ZOCs, runoff and subsurface waters were used. The $\mathrm{DOC}_{\mathrm{NC}}$ and $\mathrm{DOC}_{\mathrm{C}}$ values were determined based on the actual DOC concentrations of the raw waters and the estimated DOC removal ratio (by Eq. (2)). A linear relationship $\left(R^{2}=0.77, P<0.03\right)$ between the DOC removal rate coefficient (Eq. 1, C) and the ratio between colour/UV 254 using the same data was established. A high color/ $\mathrm{UV}_{254}$ value indicates that the dominating UV254 nm absorbing fraction in the water is from HMW-humic compounds that contribute most to the color in the water and consequently to its treatability by coagulation (Ødegaard et al., 2010). From the estimated exponential decay function parameters $\left(\mathrm{DOC}_{\mathrm{NC}}, \mathrm{DOC}_{\mathrm{C}}\right.$ and $\left.\mathrm{C}\right)$, the enhanced alum doses and residual DOC concentrations at these doses were calculated. The actual and model fitted values for the enhanced alum doses and residual DOC concentrations at these doses are shown in Supplementary information (Figs. S2a and S2b respectively) and the statistical analysis (T-test and standard error) results are also shown in Supplementary information.

The ratio of $\mathrm{DOC}$ removal at $\mathrm{HD}=\frac{a}{1+e^{-\left(\frac{x-b}{c}\right)}}$

where $\mathrm{x}=\mathrm{SUVA}+\operatorname{Ln}(100 * \mathrm{SpCol}), \mathrm{a}=$ maximum removal ratio (0.85), b and $\mathrm{c}$ are constants, $\mathrm{R}^{2}=0.82 ; \mathrm{P}<0.03$.

Organic compounds in waters of catchments with clay soils and native vegetation or grass were generally more recalcitrant to removal by alum treatment than organics of sandy soil catchments 
(Fig. 3 and S1). This is attributed to absorption of HMW and aromatic compounds onto mineral soils (Ussiri and Johnson, 2004; Banaitis et al., 2006) leading to their lower abundances in the soil water (see Fig. 2). Clays generally have a higher specific surface area and positive surface charge than quartz sands (Velde and Barré, 2010) and DOM, with an overall negative charge, can be readily adsorbed onto clay mineral surfaces (Nelson et al., 1992) or form complexes bridged by the multivalent cations of the clays (Oades, 1984). For the catchments studied, trivalent cation (e.g., $\mathrm{Al}^{3+}$ ) concentrations in waters of catchments with clay soils were higher than those of sandy soil catchments $\left(\mathrm{Al}^{3+}\right.$ concentration of $1.07 \pm 0.19 \mathrm{meq} / 100 \mathrm{~g}$ in clay soil vs. $0.77 \pm 0.19 \mathrm{meq} / 100 \mathrm{~g}$ in sandy soil). Higher concentrations of these cations in soil would result in the soil to act more as a natural coagulant.

Where there is a prominent $\mathrm{O}$ horizon and very high loadings of litter layers occur, as found at the pine sites (P-S: $5.1 \pm 2.1 \mathrm{~cm}$; P-SCL/SL: $7.4 \pm 3.1 \mathrm{~cm}$ ), the adsorption capacity of the soils appears to have been exceeded. Beyond a particular loading, there appears to be no further attenuation of DOM through soil absorption processes. The mean concentrations of DOC in the subsurface waters of the two pine sites were both high i.e. $\sim 109 \pm 55 \mathrm{mg} \mathrm{L}^{-1}$ for P-S and $\sim 112 \pm 70 \mathrm{mg} \mathrm{L}^{-1}$ for P-SCL/SL and the character of DOM are similar (Fig. 2). Consequently their treatability by alum were similar (Fig. 3). Hassink (1997) reported that there is a limit in the amount of organic carbon and nitrogen that can be absorbed by clay or silt particles of grassland and arable soils. Recent studies (Saidy et al., 2012, 2015) have reported the effect of different clay minerals on the susceptibility of plant-derived organic carbon to microbial degradation. When the organic loading exceeded the sorption capacity of minerals, these minerals had very low influence on the microbial degradation of organic materials (DOM of Medicago truncatula cv. Praggio). However, when the amount of DOM was less than the sorption capacity of minerals, the DOM was more resistant to microbial degradation, presumably through organo-mineral formations that protected the organic compounds.

These findings indicate that the adsorption capacity of soil particles, adsorption site saturation rate and the degradation and mineralization rates of organics in soils are key processes that determine the concentration and character of organics in subsurface waters. Further, the character of organics in subsurface waters may also be influenced by the transport of litter layer leachates through soil macropores, such as those formed from the decay of shrub and tree roots. This would lead to low interaction between the organics in the leachates and soil particles.

Comparison of two subsurface water collection devices in this study showed potential influence on water quality and/or water qualities in soils below and above saturation, are different. It was found that the quality of waters from shallow piezometers more closely resemble surface waters. In this study the heavily forested ZOCs of the $P$. radiata showed no overland flows and hence lysimeters were necessary to allow comparison to ZOCs with other landuses.

\section{Conclusions}

Catchment properties were found to have significant influence on the quality of source waters used for drinking water supply. DOC removal by alum coagulation was greatest in waters from ZOCs with pine vegetation, followed by Australian native vegetation and grass ZOCs. Clay soils influenced the character of organics present in surface runoff and subsurface waters in ZOCs under native vegetation and grass, and those not complexed with clay and remaining in the soil water phase are less amenable to removal by alum. The influence of the character of organics on their treatability by alum was identified based on the abundances of aromatic, humic-like compounds and protein-like compounds in waters. Organic compounds in subsurface waters of the two pine ZOCs studied were minimally influenced by their soil textures and their treatability by alum was found to be similar.

The water quality parameters of Specific colour and SUVA can be applied in models to predict alum doses to maximize removal of organic compounds (enhanced coagulation) from waters of catchments with various land management practices. A 'micro' jar testing procedure can be applied to assess the treatability of organics present in small volumes as collected by lysimeters. This micro jar test procedure closely mirrored the standard jar test procedure applied in the water industry.

\section{Acknowledgements}

The authors gratefully acknowledge the financial support provided by the Australian Research Council (ARC) under Grant LP110200208, SA Water and the SA Department for Environment, Water and Natural Resources and the Goyder Institute for Water Research. The authors thank Mr Justin Monier for his work in establishing and conducting micro jar tests and $\mathrm{Mr}$ Jonathan Cohen for his support in field work.

\section{Appendix A. Supplementary data}

Supplementary data related to this article can be found at http: //dx.doi.org/10.1016/j.chemosphere.2015.09.066.

\section{References}

Ågren, A., Buffam, I., Jansson, M., Laudon, H., 2007. Importance of seasonality and small streams for the landscape regulation of dissolved organic carbon export. J. Geophys. Res. Biogeosci 112, 2005-2012.

Awad, J., van Leeuwen, J., Abate, D., Pichler, M., Bestland, E., Chittleborough, D.J., Fleming, N., Cohen, J., Liffner, J., Drikas, M., 2015. The effect of vegetation and soil texture on the nature of organics in runoff from a catchment supplying water for domestic consumption. Sci. Total Environ. 529, 72-81.

Banaitis, M.R., Waldrip-Dail, H., Diehl, M.S., Holmes, B.C., Hunt, J.F., Lynch, R.P., Ohno, T., 2006. Investigating sorption-driven dissolved organic matter fractionation by multidimensional fluorescence spectroscopy and PARAFAC. J. Colloid Interface Sci. 304, 271-276.

Bryan, B.A., Kandulu, J., Deere, D.A., White, M., Frizenschaf, J., Crossman, N.D., 2009. Adaptive management for mitigating cryptosporidium risk in source water: a case study in an agricultural catchment in South Australia. J. Environ. Manag. 90, 3122-3134

Chantigny, M.H., 2003. Dissolved and water-extractable organic matter in soils: a review on the influence of land use and management practices. Geoderma 113, 357-380.

Chen, W., Westerhoff, P., Leenheer, J.A., Booksh, K., 2003. Fluorescence excitation-emission matrix regional integration to quantify spectra for dissolved organic matter. Environ. Sci. Technol. 37, 5701-5710.

Chow, A.T., O'Geen, A.T., Dahlgren, R.A., Díaz, F.J., Wong, K.-H., Wong, P.-K., 2011. Reactivity of litter leachates from California oak woodlands in the formation of disinfection by-products. J. Environ. Qual. 40, 1607-1616.

Chow, C.W.K., van Leeuwen, J.A., Fabris, R., Drikas, M., 2009. Optimised coagulation using aluminium sulfate for the removal of dissolved organic carbon. Desalination 245, 120-134.

Dietrich, W.E., Reneau, S.L., Wilson, C.J., 1987. Overview: “Zero-order basins" and problems of drainage density, sediment transport and hillslope morphology. IAHS Pub 165, 49-59.

Drikas, M., Chow, C.W., Cook, D., 2003. The impact of recalcitrant organic character on disinfection stability, trihalomethane formation and bacterial regrowth: an evaluation of magnetic ion exchange resin $\left(\right.$ MIEX $\left.^{\circledR}\right)$ and alum coagulation. J. Water Supply Res. Technol. AQUA 52, 475-487.

Edzwald, J.K., Tobiason, J.E., 1999. Enhanced coagulation: US requirements and a broader view. Environ. Sci. Technol. 40, 63-70.

Fabris, R., Chow, C.W.K., Drikas, M., Eikebrokk, B., 2008. Comparison of NOM character in selected Australian and Norwegian drinking waters. Water Res. 42, 41884196.

Hassink, J., 1997. The capacity of soils to preserve organic C and $\mathrm{N}$ by their association with clay and silt particles. Plant Soil 191, 77-87.

Inamdar, S., Finger, N., Singh, S., Mitchell, M., Levia, D., Bais, H., Scott, D., McHale, P. 2012. Dissolved organic matter (DOM) concentration and quality in a forested mid-Atlantic watershed, USA. Biogeochemistry 108, 55-76.

Kalbitz, K., Schmerwitz, J., Schwesig, D., Matzner, E., 2003. Biodegradation of soilderived dissolved organic matter as related to its properties. Geoderma 113 273-291.

Leinweber, P., Schulten, H.-R., Kalbitz, K., Meißner, R., Jancke, H., 2001. Fulvic acid composition in degraded fenlands. J. Plant Nutr. Soil Sci. 164, 371-379. 
1200

J. Award et al./Chemosphere 144 (2016) 1193-1200

Matilainen, A., Vepsäläinen, M., Sillanpää, M., 2010. Natural organic matter removal by coagulation during drinking water treatment: a review. Adv. Colloid Interface 159, 189-197.

Marques, R., Ranger, J., Gelhaye, D., Poller, B., Ponette, Q., GEDDert, O., 1996. Comparson of chemical composition of soil solutions collected by zero-tension plate lysimeter with those from ceramic-cup lysimeter in a forest soil. Eur. J. Soil Sci. 47, 407-417.

McElmurry, S.P., Long, D.T., Voice, T.C., 2014. Stormwater dissolved organic Matter: Influence of land cover and environmental factors. Environ. Sci. Technol. 48, 4553.

Naidu, R., Williamson, D., Fitzpatrick, R., Hollingsworth, I., 1993. Effect of landuse on the composition of through flow water immediately above clayey B horizons in the Warren Catchment, South Australia. Aust. J. Exp. Agric. 33, 239-244.

Nelson, P.N., Baldock, J.A., Odes, J.M., 1992. Concentration and composition of dissolved organic carbon in streams in relation to catchment soil properties. Biogeochemistry $19,27-50$.

Odes, J.M., 1984. Soil organic matter and structural stability: mechanisms and implications for management. Plant Soil 76, 319-337.

Ødegaard, H., Østerhus, S., Melin, E., Eikebrokk, B., 2010. NOM removal technologies - Norwegian experiences. DWES 3, 1-9.

Richardson, S., Postigo, C., 2012. Drinking water disinfection by-products. In: Barceló, D. (Ed.), Emerging Organic Contaminants and Human Health. Springer Berlin Heidelberg, pp. 93-137.

Sachse, A., Henrion, R., Gelbrecht, J., Steinberg, C.E.W., 2005. Classification of dissolved organic carbon (DOC) in river systems: influence of catchment characteristics and autochthonous processes. Org. Geochem. 36, 923-935.

Sanchez, N.P., Skeriotis, A.T., Miller, C.M., 2013. Assessment of dissolved organic matter fluorescence PARAFAC components before and after coagulation-filtration in a full scale water treatment plant. Water Res. 47, 1679-1690 .
Saidy, A.R., Smernik, R.J., Baldock, J.A., Kaiser, K., Sanderman, J., 2015. Microbial degradation of organic carbon sorbed to phyllosilicate clays with and without hydrous iron oxide coating. Eur. J. Soil Sci. 66, 83-94.

Saidy, A.R., Smernik, R.J., Baldock, J.A., Kaiser, K., Sanderman, J., Macdonald, L.M., 2012. Effects of clay mineralogy and hydrous iron oxides on labile organic carbon stabilisation. Geoderma 173-174, 104-110.

Sillanpää, M., Matilainen, A., 2015. Chapter 3-NOM removal by coagulation. In: Sillanpää, M. (Ed.), Natural Organic Matter in Water. Butterworth-Heinemann, pp. $55-80$.

Sun, S., Lu, J., Li, Y., Jiang, P., Chang, S., 2013. Similar quality and quantity of dissolved organic carbon under different land use systems in two Canadian and Chinese soils. J. Soils Sediments 13, 34-42.

Sutton, R., Sposito, G., 2005. Molecular structure in soil humic substances: the new view. Environ. Sci. Technol. 39, 9009-9015.

Ussiri, D.A.N., Johnson, C.E., 2004. Sorption of organic carbon fractions by spodosol mineral horizons. Soil Sci. Soc. Am. J. 68, 253-262.

van Leeuwen, J., Holmes, M., Kaeding, U., Daly, R., Bursill, D., 2009. Development and implementation of the software mEnCo to predict coagulant doses for DOC removal at full-scale WTPs in South Australia. J. Water Supply Res. Technol. AQUA 58, 291-298.

Velde, B., Barré, P., 2010. The Chemistry and Mineralogy of Plant and Soil Interactons: Plant as Manipulators of Their Environment. Soils, Plants and Clay Minerass. Springer Berlin Heidelberg, pp. 171-254.

Wilson, H.F., Xenopoulos, M.A., 2009. Effects of agricultural land use on the composition of fluvial dissolved organic matter. Nat. Geosci. 2, $37-41$.

Yang, Y., He, Z., Wang, Y., Fan, J., Liang, Z., Stoffella, P.J., 2013. Dissolved orgenic matter in relation to nutrients ( $\mathrm{N}$ and $\mathrm{P}$ ) and heavy metals in surface runoff water as affected by temporal variation and land uses - a case study from Indian River area, South Florida, USA. Agric. Water Manage. 118, $38-49$. 